\title{
Health Potential of Clery Strawberries: Enzymatic Inhibition and Anti-Candida Activity Evaluation
}

\author{
Francesco Cairone ${ }^{1,+}+\mathbb{D}$, Giovanna Simonetti ${ }^{2,+} \oplus$, Anastasia Orekhova ${ }^{3}$, Maria Antonietta Casadei ${ }^{1}$, \\ Gokhan Zengin ${ }^{4}(\mathbb{D})$ and Stefania Cesa ${ }^{1, *}$ (D)
}

1 Dipartimento di Chimica e Tecnologie del Farmaco, Università degli Studi di Roma "La Sapienza", Piazzale Aldo Moro 5, 00185 Roma, Italy; francesco.cairone@uniroma1.it (F.C.); mariaantonietta.casadei@uniroma1.it (M.A.C.)

2 Dipartimento di Biologia Ambientale, Università degli Studi di Roma "La Sapienza”, P.le Aldo Moro 5, 00185 Rome, Italy; giovanna.simonetti@uniroma1.it

3 Dipartimento di Sanità Pubblica e Malattie Infettive, Università degli Studi di Roma "La Sapienza", P.le Aldo Moro 5, 00185 Rome, Italy; anastasia.orekhova@uniroma1.it

4 Department of Biology, Science Faculty, Selcuk University, 42130 Konya, Turkey; gokhanzengin@selcuk.edu.tr

* Correspondence: stefania.cesa@uniroma1.it; Tel.: +39-0649913198; Fax: +39-0649913133

+ These authors contributed equally to this work.

check for updates

Citation: Cairone, F.; Simonetti, G.; Orekhova, A.; Casadei, M.A.; Zengin, G.; Cesa, S. Health Potential of Clery Strawberries: Enzymatic Inhibition and Anti-Candida Activity Evaluation Molecules 2021, 26, 1731. https:// doi.org/10.3390/molecules26061731

Academic Editor: Chiara Tonelli

Received: 16 February 2021

Accepted: 17 March 2021

Published: 19 March 2021

Publisher's Note: MDPI stays neutral with regard to jurisdictional claims in published maps and institutional affiliations.

Copyright: (C) 2021 by the authors. Licensee MDPI, Basel, Switzerland. This article is an open access article distributed under the terms and conditions of the Creative Commons Attribution (CC BY) license (https:/ / creativecommons.org/licenses/by/ $4.0 /)$.
Abstract: Strawberries, belonging to cultivar Clery (Fragaria $\times$ ananassa Duchesne ex Weston) and to a graft obtained by crossing Clery and Fragaria vesca L., were chosen for a study on their health potential, with regard to the prevention of chronic and degenerative diseases. Selected samples, coming from fresh and defrosted berries, submitted to different homogenization techniques combined with thermal and microwave treatments, had been previously analyzed in their polyphenolic content and antioxidant capacity. In the present work, these homogenates were evaluated in relation to their enzymatic inhibition activity towards acetylcholinesterase and butyrylcholinesterase, $\alpha$-amylase, $\alpha$-glucosidase and tyrosinase. All these enzymes, involved in the onset of diabetes, and neurodegenerative and other chronic diseases, were modulated by the tested samples. The inhibitory effect on tyrosinase and cholinesterase was the most valuable. Antifungal activity against Candida albicans, recently shown to play a crucial role in human gut diseases as well as diabetes, rheumatoid arthritis and Alzheimer's disease, was also shown in vitro and confirmed by the in vivo text on Galleria mellonella. Overall, the obtained results confirm once again the health potential of strawberries; however, the efficacy is dependent on high quality products submitted to correct processing flow charts.

Keywords: Fragaria spp.; food processing; polyphenols; bioactivity; enzymatic modulation; anti-Candida activity; Galleria mellonella model

\section{Introduction}

As is well known, many recent reports show that the onset and growth of metabolic syndrome, diabetes, inflammation, cancer, neurological and cardiovascular diseases are etiologically correlated to the reduced consumption of antioxidant molecules contained in fruits and greens. As a counterpart, the well-recognized health potential associated with the daily consumption of vegetables and fruits has represented the object of interest of many studies carried out during the last two decades [1].

Among other edible vegetables, berries, and more specifically strawberries, are particularly appreciated by this point of view, in relation to their high content of active interesting biomolecules. Belonging to the Rosaceae family, comprising a large number of edible species, Fragaria vesca L. and Fragaria $\times$ ananassa Duch. represent, respectively, the wild type and a species largely cultivated worldwide, both appreciated for their attractive characteristics, color, fragrance, taste, and high vitamin and mineral content.

These promising characteristics have prompted cultivators to trial many new crop crossings. Actually, many different species are cultivated, among which the Clery cultivar 
represented the interest of our previous [2] research. Many recent studies and reviews regarding the health benefits exerted by berries in general, and strawberries in particular, underline the special role of these fruits in the prevention of inflammation and cell damage $[3,4]$. It is well known that inflammation is dramatically correlated with cancer and chronic diseases [5] and that gut microbiota-derived products can induce inflammation and contribute to metabolic and degenerative illnesses [6].

The polyphenolic content and the health potential of Fragaria spp. were recently reported in a review [7], in which strawberries were evaluated as anticancer, anti-inflammatory, anti-obesity and chemoprotective agents, as well as for their potential in antimicrobial, anti-allergenic and anti-diabetic applications. Phenolic extracts of strawberry were also reported to inhibit Candida albicans growth [8].

Saxena et al. [9] recently reviewed the function of target enzymes and the role carried out by enzyme inhibitors in the etiology of Alzheimer's disease (AD). Okello et al. [10] reported that cholinesterase inhibitors have been recently isolated from natural sources and tested for their health potential in the prevention of $\mathrm{AD}$ onset and progression. The involvement of apoptosis of cholinergic neurons of limbic and neocortical regions makes acetylcholine-mediated neurotransmission a key factor in contrasting the associated morbidity. In addition, the levels of butyrylcholinesterase $(\mathrm{BChE})$ are increased in $\mathrm{AD}$ patients as compensation of a reduced expression of acetylcholinesterase (AChE) and the inhibition activity, exerted on both enzymes by flavan-3-ol compounds, gives these molecules renewed interest in the prevention strategies of the most seriously disabling neurodegenerative illness.

The tyrosinase enzyme, catalyzing the initial conversion of L-tyrosine in L-dopa and the subsequent oxidation in dopaquinone, which polymerizes producing melanin, is also involved in degenerative processes [11]. Implicated in the onset of the skin melanomas and in the increase of neuromelanin in nigral dopaminergic neurons, it was observed in higher contents in elderly humans and, moreover, in Parkinson's patients [12]. Taslimi et al. [11] evaluated the anti-melanogenesis potential of different molecules obtained by natural sources, evidencing that natural phenols exerted significant inhibition activity towards tyrosinase enzyme $\left(\mathrm{IC}_{50}\right.$ values ranging between 2.37 and $\left.7.90 \mu \mathrm{M}\right)$.

The anti-diabetic role exerted by foods containing functional ingredients has been known for many years and many recent papers deal with this activity. Different ellagitannins and polyphenols extracted by food and food by-products were recently evaluated in regards to their role in inhibiting $\alpha$-amylase and $\alpha$-glucosidase and so preventing obesity and associated comorbidities [13-16].

It is also well known that the human microbiota plays a preeminent role in maintaining the state of well-being. Moreover, in more recent years, papers have also suggested that the gut mycobiota may be deeply linked with health and disease. Candida spp. are common species in the mycobiota of healthy humans, but their colonization and overgrowth in the gastrointestinal tract has been considered to play a role in the pathogenesis of Crohn's disease [17], in multiple sclerosis, in amyotrophic lateral sclerosis and AD [18]. Fungal materials and Candida DNA have been detected in cerebrospinal fluid and in different brain regions including external frontal cortex, cerebellar hemispheres, entorhinal cortex/hippocampus and choroid plexus of AD patients [19-21]. Moreover, it has been reported that $C$. albicans cells cause cerebritis and a mild memory impairment [22] and that a correlation exists between Candida infections, $\beta$-amyloid increase and AD severity [23].

As shown by the results obtained in our previous work [2], quality parameters of Clery strawberries, such as polyphenol content, are deeply influenced by applying different procedural techniques. The conclusions of this work allowed us to observe that anthocyanins, flavanols and phenolic acid content were strictly correlated to the applied workflow, highlighting protective effects exerted by pasteurization and negative effects caused by blanching treatment.

On the basis of this premise, the obtained homogenates from Clery strawberries, previously analyzed [2], and some new samples of a Clery graft on Fragaria vesca were submitted 
to a multimethodological evaluation of their bioactivity, aiming to predict their ability in preventing degenerative and chronic diseases, testing the enzymatic inhibition activity on acetyl (AChE) and butyrylcholinesterase (BChE), tyrosinase, $\alpha$-amylase and $\alpha$-glucosidase. Moreover, the antifungal activity was demonstrated in vitro against $C$. albicans planktonic and sessile cells and C. albicans biofilm formation, and in vivo in a Galleria mellonella waxworm infection model.

\section{Results and Discussion}

The results of our previous work [2] allowed us to discover how deeply the processing steps could affect the final characteristics of processed food, independently from their stated quality. Similar research on strawberries, strawberry juice and blackberries was carried out by Patras et al. [24] and Karacam et al. [25], and we have conducted analogue experiments on blueberries and goji berries [26,27]. Overall, these papers show that quality parameters are deeply influenced by thermal, microwave and homogenization treatments.

If different homogenization techniques alone are able to modify color and fragrance of starting food materials, when the homogenization is combined with very mild heat treatment, such as blanching, fast pasteurization or mild microwave treatment, important modifications in total phenolic content, total flavonoid content, antioxidant and antiradical activity are shown. Moreover, HPLC and GC analysis allows us to show significant differences in single molecule content as well as in several classes of analyzed compounds [2]. In Table 1 all the obtained and tested samples are reported.

Table 1. Sample legend.

\begin{tabular}{|c|c|c|c|}
\hline Sample & Treatment & Sample & Treatment \\
\hline M & Homogenized with mixer & $\mathrm{U}$ & Homogenized with Ultraturrax ${ }^{\circledR}$ \\
\hline M def & $\begin{array}{l}\text { Defrosted and homogenized } \\
\text { with mixer }\end{array}$ & U def & $\begin{array}{l}\text { Defrosted and homogenized } \\
\text { with Ultraturrax }{ }^{\circledR}\end{array}$ \\
\hline $\mathrm{MP}$ & $\begin{array}{l}\text { Homogenized with mixer } \\
\text { and pasteurized }\end{array}$ & UP & $\begin{array}{l}\text { Homogenized with Ultraturrax } \\
\text { and pasteurized }\end{array}$ \\
\hline $\mathrm{BM}$ & $\begin{array}{l}\text { Blanched and homogenized } \\
\text { with mixer }\end{array}$ & $\mathrm{BU}$ & $\begin{array}{l}\text { Blanched and homogenized } \\
\text { with Ultraturrax }{ }^{\circledR}\end{array}$ \\
\hline $\mathrm{BMP}$ & $\begin{array}{l}\text { Blanched, homogenized with } \\
\text { mixer and pasteurized }\end{array}$ & BUP & $\begin{array}{l}\text { Blanched, homogenized with } \\
\text { Ultraturrax }{ }^{\circledR} \text { and pasteurized }\end{array}$ \\
\hline WM & $\begin{array}{l}\text { Treated with microwaves } \\
\text { and homogenized with mixer }\end{array}$ & WU & $\begin{array}{c}\text { Treated with microwaves and } \\
\text { homogenized with Ultraturrax }\end{array}$ \\
\hline $\mathrm{PM}$ & $\begin{array}{c}\text { Pasteurized and } \\
\text { homogenized with mixer }\end{array}$ & PU & $\begin{array}{c}\text { Pasteurized and homogenized } \\
\text { with Ultraturrax }{ }^{\circledR}\end{array}$ \\
\hline PM def & $\begin{array}{l}\text { Defrosted, pasteurized and } \\
\text { homogenized with mixer }\end{array}$ & PU def & $\begin{array}{c}\text { Defrosted, pasteurized and } \\
\text { homogenized with Ultraturrax }\end{array}$ \\
\hline PM imm. & $\begin{array}{l}\text { Immature fruits pasteurized } \\
\text { and homogenized with mixer }\end{array}$ & PU imm. & $\begin{array}{l}\text { Immature fruits pasteurized and } \\
\text { homogenized with Ultraturrax }\end{array}$ \\
\hline M graft & $\begin{array}{l}\text { Graft Clery/F. vesca } \\
\text { homogenized with mixer }\end{array}$ & U graft & $\begin{array}{c}\text { Graft Clery/F. vesca } \\
\text { homogenized with Ultraturrax }{ }^{\circledR}\end{array}$ \\
\hline M def graft & $\begin{array}{l}\text { Graft Clery/F. vesca defrosted } \\
\text { and homogenized with mixer }\end{array}$ & U def graft & $\begin{array}{c}\text { Graft Clery/F. vesca defrosted } \\
\text { and homogenized with } \\
\text { Ultraturrax }{ }^{\circledR}\end{array}$ \\
\hline MP graft & $\begin{array}{l}\text { Graft Clery/F. vesca } \\
\text { homogenized with mixer } \\
\text { and pasteurized }\end{array}$ & UP graft & $\begin{array}{l}\text { Graft Clery/F. vesca } \\
\text { homogenized with Ultraturrax } \\
\text { and pasteurized }\end{array}$ \\
\hline
\end{tabular}


Table 1. Cont.

\begin{tabular}{cccc}
\hline Sample & Treatment & Sample & Treatment \\
\hline BM graft & $\begin{array}{c}\text { Graft Clery/F. vesca defrosted } \\
\text { and homogenized with mixer }\end{array}$ & BU graft & $\begin{array}{c}\text { Graft Clery/F. vesca defrosted } \\
\text { and homogenized with } \\
\text { Ultraturrax }{ }^{\circledR}\end{array}$ \\
\hline WM graft & $\begin{array}{c}\text { Graft Clery/F. vesca treated } \\
\text { with microwaves and } \\
\text { homogenized with mixer }\end{array}$ & WU graft & $\begin{array}{c}\text { Graft Clery } / F \text {. vesca treated with } \\
\text { microwaves and homogenized } \\
\text { with Ultraturrax }{ }^{\circledR}\end{array}$ \\
\hline PM graft & $\begin{array}{c}\text { Graft Clery/F. vesca } \\
\text { pasteurized and } \\
\text { homogenized with mixer }\end{array}$ & PU graft & $\begin{array}{c}\text { Graft Clery } / F \text {. vesca pasteurized } \\
\text { and homogenized with } \\
\text { Ultraturrax }{ }^{\circledR}\end{array}$ \\
\hline BMP graft & $\begin{array}{c}\text { Graft Clery/F. vesca defrosted } \\
\text { and homogenized with mixer }\end{array}$ & BUP graft & $\begin{array}{c}\text { Graft Clery } / F \text {. vesca defrosted } \\
\text { and homogenized with } \\
\text { Ultraturrax }{ }^{\circledR}\end{array}$ \\
\hline
\end{tabular}

With the aim to highlight the best workflow in terms of bioactives preservation, a further step was performed in the present work by selecting some of the obtained homogenates and monitoring them in relation to their residue bioactivity, evaluated in terms of enzyme inhibition and antifungal activity.

\subsection{Enzyme Inhibition Activities}

The effects of the strawberry samples on a large panel of important enzymes are reported in Table 2. Collectively, the inhibitory activities were homogeneous within the different treatments applied to the samples (blanching, homogenization, pasteurization, microwave-based effects), between defrosted or fresh fruits, and between Clery and Clery grafts on Fragaria vesca. Based on $\mathrm{IC}_{50}$ values $(\mathrm{mg} / \mathrm{mL}), \mathrm{AChE}$ inhibitory effects varied from $1.03 \mathrm{mg} / \mathrm{mL}$ (in WU) to $1.95 \mathrm{mg} / \mathrm{mL}$ (WU graft). Regarding BChE inhibition, the highest and lowest abilities were found in the PM graft $\left(\mathrm{IC}_{50}: 1.81 \mathrm{mg} / \mathrm{mL}\right)$ and $\mathrm{MP}$ graft $\left(\mathrm{IC}_{50}: 2.97 \mathrm{mg} / \mathrm{mL}\right.$ ). The tested samples exhibited similar tyrosinase ability and the range was found to be $1.60-2.03 \mathrm{mg} / \mathrm{mL}$. WU and PM exhibited the strongest amylase inhibitory actions with those values of 3.76 and $8.83 \mathrm{mg} / \mathrm{mL}$, respectively. Glucosidase inhibition abilities of the tested samples were close to each other $\left(\mathrm{IC}_{50}: 1.00-1.44 \mathrm{mg} / \mathrm{mL}\right)$.

Table 2. Enzyme inhibitory results ( $\mathrm{IC}_{50}: \mathrm{mg} / \mathrm{mL}$ ) of strawberry samples and standards against different enzymes.

\begin{tabular}{|c|c|c|c|c|c|}
\hline Sample & AChE Inhibition & BChE Inhibition & $\begin{array}{l}\text { Tyrosinase } \\
\text { Inhibition }\end{array}$ & $\begin{array}{l}\alpha \text {-Amylase } \\
\text { Inhibition }\end{array}$ & $\begin{array}{l}\alpha \text {-Glucosidase } \\
\text { Inhibition }\end{array}$ \\
\hline M & $1.16 \pm 0.01^{\mathrm{jkl}}$ & $2.40 \pm 0.33^{a b}$ & $1.92 \pm 0.01^{\text {abcdefg }}$ & $12.84 \pm 4.19^{\operatorname{defg}}$ & $1.00 \pm 0.01^{\mathrm{d}}$ \\
\hline $\mathrm{U}$ & $1.15 \pm 0.01^{\mathrm{kl}}$ & $2.23 \pm 0.48^{a b}$ & $1.94 \pm 0.01$ abcde & $16.87 \pm 2.28$ abcde & $1.00 \pm 0.01^{\mathrm{d}}$ \\
\hline M def & $1.40 \pm 0.01^{\text {efg }}$ & $2.17 \pm 0.27^{\mathrm{ab}}$ & $1.79 \pm 0.01$ hijk & $17.02 \pm 0.31^{\mathrm{abcd}}$ & $1.00 \pm 0.01^{\mathrm{d}}$ \\
\hline U def & $1.17 \pm 0.01^{\mathrm{jk}}$ & $2.17 \pm 0.27^{\mathrm{ab}}$ & $2.01 \pm 0.02^{a}$ & $21.18 \pm 0.13^{a}$ & $1.00 \pm 0.01^{\mathrm{d}}$ \\
\hline MP & $1.23 \pm 0.02^{\mathrm{ijk}}$ & $2.37 \pm 0.26^{\mathrm{ab}}$ & $1.81 \pm 0.05^{\text {ghijk }}$ & $10.65 \pm 2.28^{\mathrm{fg}}$ & $\mathrm{ni}$ \\
\hline UP & $1.19 \pm 0.01^{\mathrm{jk}}$ & $2.27 \pm 0.36^{\mathrm{ab}}$ & $1.87 \pm 0.04^{\text {cdefghi }}$ & $14.10 \pm 2.66^{\text {cdef }}$ & $1.00 \pm 0.01^{\mathrm{d}}$ \\
\hline $\mathrm{BM}$ & $1.25 \pm 0.03$ hij & $2.967 \pm 0.43^{a}$ & $1.95 \pm 0.02^{\mathrm{abcd}}$ & $20.12 \pm 0.17^{a b}$ & $1.00 \pm 0.01^{\mathrm{d}}$ \\
\hline $\mathrm{BU}$ & $1.51 \pm 0.05^{\mathrm{d}}$ & $2.18 \pm 0.07^{a b}$ & $1.97 \pm 0.02 \mathrm{abc}$ & $19.82 \pm 0.81^{\mathrm{ab}}$ & $1.01 \pm 0.01^{\mathrm{d}}$ \\
\hline BMP & $1.21 \pm 0.01 \mathrm{ijk}$ & $2.13 \pm 0.35^{\mathrm{ab}}$ & $1.94 \pm 0.09$ abcde & $12.57 \pm 0.92^{\text {defg }}$ & $1.00 \pm 0.01^{\mathrm{d}}$ \\
\hline BUP & $1.25 \pm 0.0^{\text {hij }}$ & $2.40 \pm 0.38^{a b}$ & $1.83 \pm 0.02$ efghij & $15.54 \pm 1.63^{\text {bcde }}$ & ni \\
\hline WM & $1.07 \pm 0.01 \mathrm{~lm}$ & $2.25 \pm 0.45^{\mathrm{ab}}$ & $1.92 \pm 0.05^{\text {abcdefg }}$ & $12.10 \pm 2.61 \mathrm{efg}$ & $1.00 \pm 0.01^{\mathrm{d}}$ \\
\hline
\end{tabular}


Table 2. Cont.

\begin{tabular}{|c|c|c|c|c|c|}
\hline Sample & AChE Inhibition & BChE Inhibition & $\begin{array}{l}\text { Tyrosinase } \\
\text { Inhibition }\end{array}$ & $\begin{array}{l}\alpha \text {-Amylase } \\
\text { Inhibition }\end{array}$ & $\begin{array}{c}\alpha \text {-Glucosidase } \\
\text { Inhibition }\end{array}$ \\
\hline WU & $1.03 \pm 0.01 \mathrm{~m}$ & $1.99 \pm 0.06^{\mathrm{ab}}$ & $1.60 \pm 0.02^{1}$ & $3.76 \pm 0.05^{h}$ & $1.01 \pm 0.01^{\mathrm{d}}$ \\
\hline PM & $1.16 \pm 0.02^{\mathrm{jkl}}$ & $2.06 \pm 0.30^{\mathrm{ab}}$ & $1.87 \pm 0.02$ cdefghi & $8.83 \pm 2.09 \mathrm{~g}$ & ni \\
\hline PU & $1.34 \pm 0.02 \mathrm{gh}$ & $2.07 \pm 0.27^{a b}$ & $1.73 \pm 0.02^{\mathrm{jk}}$ & $14.25 \pm 0.39$ cdef & $1.00 \pm 0.01^{\mathrm{d}}$ \\
\hline M graft & $1.14 \pm 0.01^{\mathrm{kl}}$ & $2.35 \pm 0.20^{\mathrm{ab}}$ & $1.77 \pm 0.0^{1 \mathrm{ijk}}$ & $16.82 \pm 0.56^{\text {abcde }}$ & $1.00 \pm 0.01^{\mathrm{d}}$ \\
\hline U graft & $1.46 \pm 0.01 \mathrm{def}$ & $2.19 \pm 0.32^{a b}$ & $1.86 \pm 0.02$ cdefghi & $18.32 \pm 1.03^{a b c}$ & $1.01 \pm 0.01^{\mathrm{d}}$ \\
\hline M def graft & $1.66 \pm 0.03^{c}$ & $2.62 \pm 0.43^{a b}$ & $2.03 \pm 0.05^{\mathrm{a}}$ & $17.20 \pm 0.57^{\mathrm{abcd}}$ & $1.24 \pm 0.08^{b}$ \\
\hline U def graft & $1.37 \pm 0.03 \mathrm{fg}$ & $2.25 \pm 0.05^{\mathrm{ab}}$ & $2.00 \pm 0.05^{a b}$ & $16.69 \pm 2.79$ abcde & $1.06 \pm 0.01^{\mathrm{d}}$ \\
\hline MP graft & $1.16 \pm 0.01^{\mathrm{jkl}}$ & $2.97 \pm 0.18^{a}$ & $1.71 \pm 0.02^{\mathrm{kl}}$ & $14.05 \pm 1.46^{\mathrm{cdef}}$ & $1.00 \pm 0.01^{\mathrm{d}}$ \\
\hline UP graft & $1.25 \pm 0.04^{\mathrm{hij}}$ & $2.50 \pm 0.33^{a b}$ & $1.81 \pm 0.02$ ghijk & $15.48 \pm 0.57^{\text {bcde }}$ & $1.00 \pm 0.01^{\mathrm{d}}$ \\
\hline BM graft & $1.66 \pm 0.03^{c}$ & $2.15 \pm 0.25^{a b}$ & $1.97 \pm 0.05^{a b c}$ & $16.13 \pm 0.07^{\text {bcde }}$ & $1.00 \pm 0.01^{\mathrm{d}}$ \\
\hline BU graft & $1.40 \pm 0.05^{\text {efg }}$ & $1.99 \pm 0.26^{\mathrm{ab}}$ & $1.94 \pm 0.03$ abcdef & $16.30 \pm 0.39$ bcde & $1.00 \pm 0.01^{\mathrm{d}}$ \\
\hline BMP graft & $1.31 \pm 0.01 \mathrm{ghi}$ & $2.61 \pm 0.52^{a b}$ & $1.84 \pm 0.03$ defghij & $18.33 \pm 0.33^{a b c}$ & $1.00 \pm 0.01^{\mathrm{d}}$ \\
\hline BUP graft & $1.79 \pm 0.05^{b}$ & $2.22 \pm 0.15^{\mathrm{ab}}$ & $1.86 \pm 0.02$ cdefghi & $17.86 \pm 1.48^{a b c}$ & $1.44 \pm 0.05^{\mathrm{a}}$ \\
\hline WM graft & $1.88 \pm 0.02^{\mathrm{ab}}$ & $2.60 \pm 0.53^{a b}$ & $1.94 \pm 0.09$ abcde & $17.94 \pm 1.54^{a b c}$ & $1.01 \pm 0.01^{\mathrm{d}}$ \\
\hline WU graft & $1.95 \pm 0.05^{\mathrm{a}}$ & $2.13 \pm 0.53^{a b}$ & $1.89 \pm 0.03$ bcdefgh & $15.66 \pm 0.23$ bcde & $1.00 \pm 0.01^{\mathrm{d}}$ \\
\hline PM graft & $1.21 \pm 0.02^{\mathrm{ijk}}$ & $1.81 \pm 0.13^{b}$ & $1.82 \pm 0.03^{\text {fghij }}$ & $15.81 \pm 1.12^{\text {bcde }}$ & $1.02 \pm 0.01^{\mathrm{d}}$ \\
\hline PU graft & $1.48 \pm 0.04^{\mathrm{de}}$ & $2.29 \pm 0.10^{a b}$ & $1.81 \pm 0.01$ ghijk & $12.73 \pm 0.34$ defg & $1.14 \pm 0.03^{c}$ \\
\hline Galantamine & $0.003 \pm 0.0001^{n}$ & $0.007 \pm 0.0001^{\mathrm{c}}$ & nt & $\mathrm{nt}$ & $\mathrm{nt}$ \\
\hline Kojic acid & nt & $\mathrm{nt}$ & $0.08 \pm 0.01^{\mathrm{m}}$ & nt & $\mathrm{nt}$ \\
\hline Acarbose & $\mathrm{nt}$ & nt & $\mathrm{nt}$ & $0.86 \pm 0.01^{h}$ & $1.28 \pm 0.04^{b}$ \\
\hline
\end{tabular}

Values are reported as mean \pm SD of three parallel experiments; ni: no inhibition; nt: not tested. Different letters (a-n) in same column indicate significant differences in the tested samples $(p<0.05)$.

\subsection{Antifungal Activity}

The texted Clery strawberry samples showed in vitro antifungal activity against C. albicans strains, with $\mathrm{GMMIC}_{50}$ ranging from $19.36 \mu \mathrm{g} / \mathrm{mL}$ to $59.82 \mu \mathrm{g} / \mathrm{mL}$ and $\mathrm{MIC}_{90}$ values ranging from $68.13 \mu \mathrm{g} / \mathrm{mL}$ to $162.09 \mu \mathrm{g} / \mathrm{mL}$. PU showed the best $\mathrm{MIC}_{50}$ values against ATCC 24433 with values of $2.92 \mu \mathrm{g} / \mathrm{mL}$ (Table 3).

Table 3. Antifungal activity of Clery strawberry samples against four strains of Candida albicans (Antifungal activity was determined according to Clinical and Laboratory Standards Institute guidelines (CLSI document M38-A2, 2008). Minimal inhibitory concentration (MIC) was determined. $\mathrm{MIC}_{50}$ and $\mathrm{MIC}_{90}=$ the lowest drug concentration that prevented $50 \%$ and $90 \%$ of growth with respect to the untreated control, respectively. The values shown are the median from three independent measurements).

\begin{tabular}{ccccc}
\hline \multirow{2}{*}{ Sample } & \multicolumn{4}{c}{ Candida albicans } \\
\cline { 2 - 5 } & ATCC 90028 & ATCC10231 & ATCC24433 & 3153A \\
\cline { 2 - 5 } & & Median MIC $_{\mathbf{5 0}}(\boldsymbol{\mu} \mathbf{g} / \mathbf{m L})$ \\
\hline M & 312.5 & 7.8 & 11.7 & 156.25 \\
\hline U & 93.75 & 23.42 & 5.85 & 62.5 \\
\hline MP & 257.8 & 7.8 & 3.9 & 62.5 \\
\hline UP & 93.75 & 7.8 & 3.9 & 62.5 \\
\hline BM & 156.25 & 7.8 & 5.85 & 62.5 \\
\hline
\end{tabular}


Table 3. Cont.

\begin{tabular}{|c|c|c|c|c|}
\hline \multirow{3}{*}{ Sample } & \multicolumn{4}{|c|}{ Candida albicans } \\
\hline & ATCC 90028 & ATCC10231 & ATCC24433 & $3153 \mathrm{~A}$ \\
\hline & \multicolumn{4}{|c|}{ Median MIC $_{50}(\mu \mathrm{g} / \mathrm{mL})$} \\
\hline $\mathrm{BU}$ & 187.5 & 11.7 & 3.9 & 93.75 \\
\hline $\mathrm{BMP}$ & 93.75 & 11.7 & 7.8 & 62.5 \\
\hline BUP & 46.87 & 3.9 & 3.9 & 62.5 \\
\hline WM & 312.5 & 7.8 & 5.85 & 62.5 \\
\hline WU & 281.25 & 7.8 & 7.8 & 93.75 \\
\hline PM & 312.5 & 11.7 & 11.7 & 156.25 \\
\hline PU & 281.25 & 5.85 & 2.92 & 62.5 \\
\hline PM def. & 375 & 46.87 & 5.85 & 31.25 \\
\hline PU def. & 187.5 & 46.87 & 9.75 & 62.5 \\
\hline PM imm. & 375 & 23.42 & 4.85 & 31.25 \\
\hline \multirow[t]{2}{*}{ PU imm. } & 187.5 & 62.5 & 15.6 & 93.75 \\
\hline & \multicolumn{4}{|c|}{ Median MIC $_{90}(\mu \mathrm{g} / \mathrm{mL})$} \\
\hline M & $>1000$ & 62.5 & 23.42 & 156.25 \\
\hline $\mathrm{U}$ & 1000 & 78.12 & 15.6 & 62.5 \\
\hline $\mathrm{MP}$ & $>1000$ & 62.5 & 7.8 & 62.5 \\
\hline UP & 750 & 62.5 & 7.8 & 62.5 \\
\hline $\mathrm{BM}$ & 1000 & 187.5 & 7.8 & 62.5 \\
\hline $\mathrm{BU}$ & 1000 & 93.75 & 23.42 & 93.75 \\
\hline $\mathrm{BMP}$ & 1000 & 62.5 & 11.7 & 62.5 \\
\hline BUP & 1000 & 93.75 & 7.8 & 62.5 \\
\hline WM & $>1000$ & 187.5 & 15.6 & 62.5 \\
\hline WU & 1000 & 62.5 & 19.52 & 93.75 \\
\hline PM & $>1000$ & 62.5 & 23.42 & 281.25 \\
\hline PU & $>1000$ & 250 & 7.8 & 62.5 \\
\hline PM def. & $>1000$ & 93.75 & 7.8 & 31.25 \\
\hline PU def. & 1000 & 187.5 & 15.6 & 93.75 \\
\hline PM imm. & $>1000$ & 62.5 & 7.8 & 31.25 \\
\hline PU imm. & 1000 & 187.5 & 31.25 & 125 \\
\hline
\end{tabular}

Given the activity on planktonic cells, we wanted to see if activity on Candida biofilm could also be shown. In fact, C. albicans produces highly structured biofilms composed of yeast cells, pseudo-hyphal cells and hyphal cells, largely resistant to current antifungal drugs, representing a significant part of $C$. albicans virulence. The results obtained using different concentrations of PU extract against Candida biofilm formation were highly encouraging. These demonstrated that $80 \%$ of biofilm onset was inhibited with PU extract at a concentration of $500 \mu \mathrm{g} / \mathrm{mL}$.

Moreover, just for an extract concentration of $62.5 \mu \mathrm{g} / \mathrm{mL}$, about $60 \%$ of the biofilm generated by two of the three tested strains was inhibited (Figure 1). 


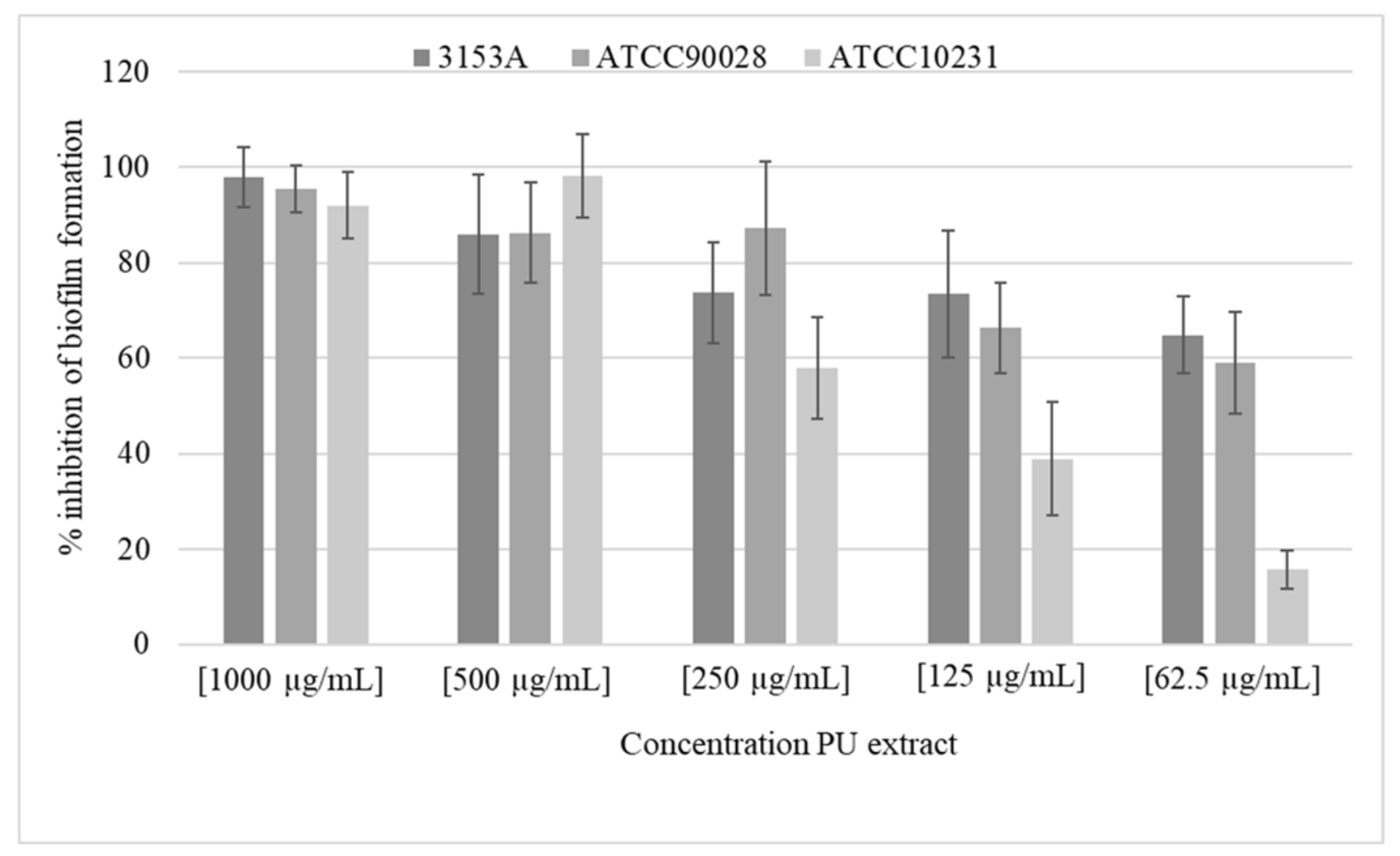

Figure 1. Inhibition of C. albicans biofilm formation using PU sample.

The G. mellonella model, positively correlated with results from studies with Caenorhabditis elegans and mice [28], represents a simple and inexpensive alternative method for the rapid evaluation of antimicrobial drug effectiveness in vivo. On the basis of the encouraging results reported above, we proceeded by testing the PU extract activity on C. albicans ATCC10231, using the G. mellonella model. The obtained results (Table 4) confirmed the previously obtained results, showing that PU administered to the larvae is able to increase their survival, if compared to those only inoculated with Candida.

Table 4. \% of survival rate of G. mellonella infected with C. albicans and treated with PU after 24, 48 and $72 \mathrm{~h}$ of incubation.

\begin{tabular}{cccc}
\hline & \multicolumn{3}{c}{$\%$ of Survival Rate } \\
\cline { 2 - 4 } & $\mathbf{2 4} \mathbf{h}$ & $\mathbf{4 8 ~ h}$ & $\mathbf{7 2 ~ h}$ \\
\hline Control larvae & $100 \%$ & $100 \%$ & $100 \%$ \\
\hline Pierced larvae & $100 \%$ & $100 \%$ & $100 \%$ \\
\hline PBS & $100 \%$ & $60 \%$ & $60 \%$ \\
\hline C. albicans ATCC $1000 \mu \mathrm{g} / \mathrm{mL}$ & $100 \%$ & $100 \%$ & $100 \%$ \\
\hline C. albicans ATCC $10231+\mathrm{PU} 1000 \mu \mathrm{g} / \mathrm{mL}$ & $40 \%$ & 0 & 0 \\
\hline
\end{tabular}

Flavonoids were demonstrated to inhibit fungal growth with different mechanisms, such as plasma membrane disruption, mitochondrial dysfunction, inhibition of RNA and protein synthesis, cell division, cell wall formation and the efflux pump systems [29]. As different flavonoids and flavanoids (with particular regard for epicatechin, which accounted for $316 \mu \mathrm{g} / \mathrm{g}$ in PU vs a median of $250 \mu \mathrm{g} / \mathrm{g}$ for the whole U Series) detected in strawberries were especially represented in sample PU [30], we could attribute the showed 
efficacy to this class of compounds. We can also conclude that Clery strawberry fruits, only mildly pasteurized and homogenized, could be a useful matrix to be investigated as innovative and cost-effective anti-mycotic agents.

\subsection{Principal Component Analysis (PCA)}

PCA (principal component analysis) was conducted in order to correlate the previously published data of fresh Clery strawberry samples [2] and the data related to fresh Clery strawberry graft samples (reported in Supplementary Materials, Tables S1 and S2) with enzymatic inhibition activity and antifungal activity. The values were scaled using XLSTAT 2020 software, with the unit variance scale. As shown in Figure 2, related to PCA plots of the fresh analyzed Clery samples, the x-axis represents the first PCA dimension (F1) covering $51 \%$ of the total variance, whereas the y-axis is the second PCA dimension (F2) covering $29 \%$ of the total variance.

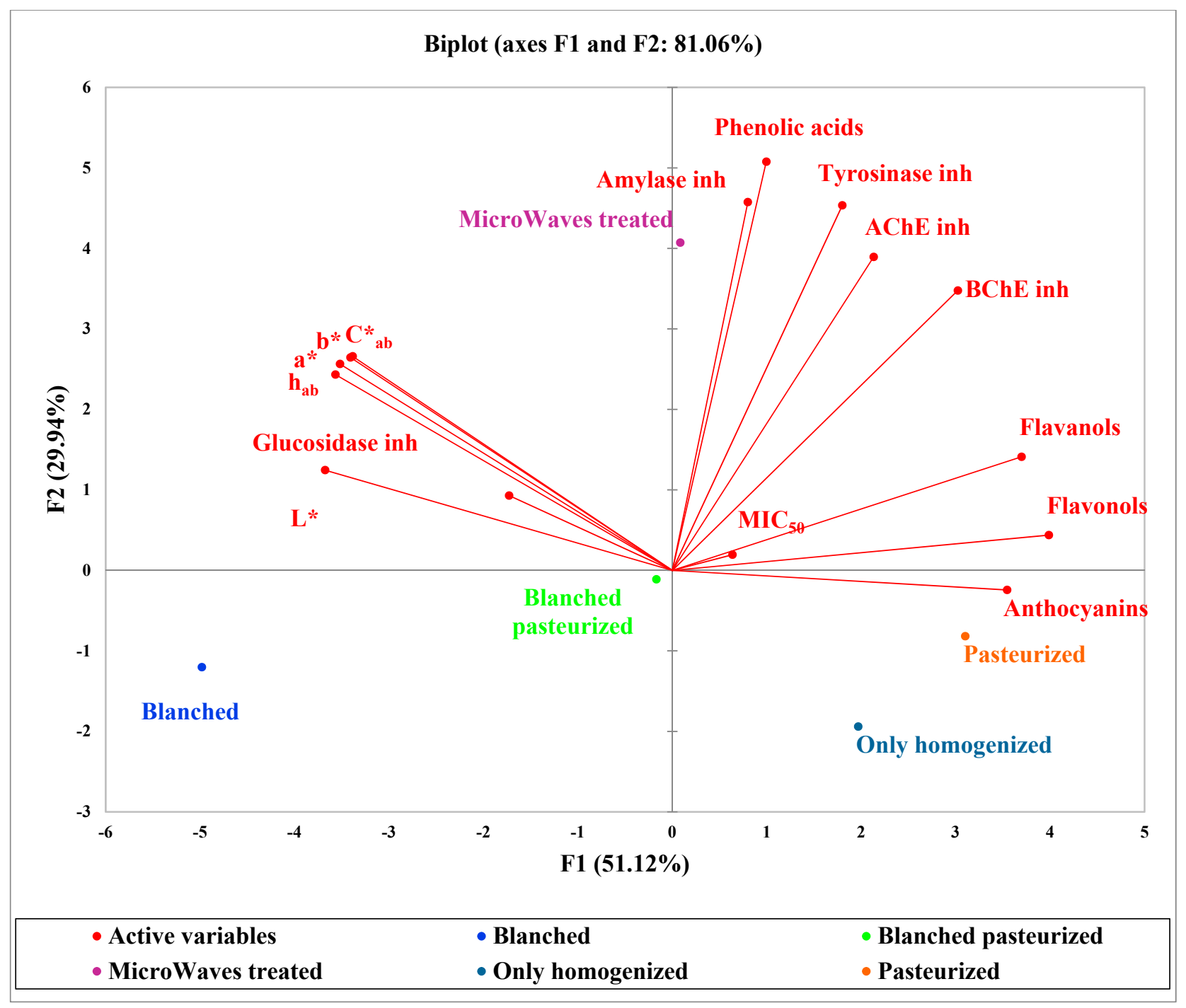

Figure 2. Principal component analysis (PCA) plots of the fresh analyzed Clery samples evaluated as series.

The red vectors indicate the investigated variables. It is possible to show that the main molecules correlated to enzymatic and antifungal activity are phenolic acids, flavonols and flavanols (the first quadrant in the PCA plot, Figure 2). From this point of view, the microwave-treated samples appear to show the best enzymatic inhibition activity, and the pasteurized samples are more correlated with the antifungal inhibition activity, suggesting 
a greater potential of samples submitted to this kind of treatment. In fact, as reported in Garzoli et al. [2], the microwave-treated and pasteurized samples showed the highest content of phenolic acids, flavanols and flavonols.

The pasteurized and only homogenized samples (fourth quadrant in the PCA plot, Figure 2), highly correlated with the anthocyanins content, do not show the highest enzymatic inhibition, indicating a lower involvement of the anthocyanins in this kind of activity, as also reported in another study available in the literature [31]. Finally, as expected, the blanching treatments (third quadrant in the PCA plot, Figure 2), having a greater impact on the strawberry phytocomplex [2], is correlated with the lowest enzymatic inhibition and antifungal activity.

In Figure 3 are reported the PCA plots of the fresh analyzed Clery graft samples. The $x$-axis represents the first PCA dimension (F1) covering $53 \%$ of the total variance, whereas the y-axis is the second PCA dimension (F2) covering $26 \%$ of the total variance.

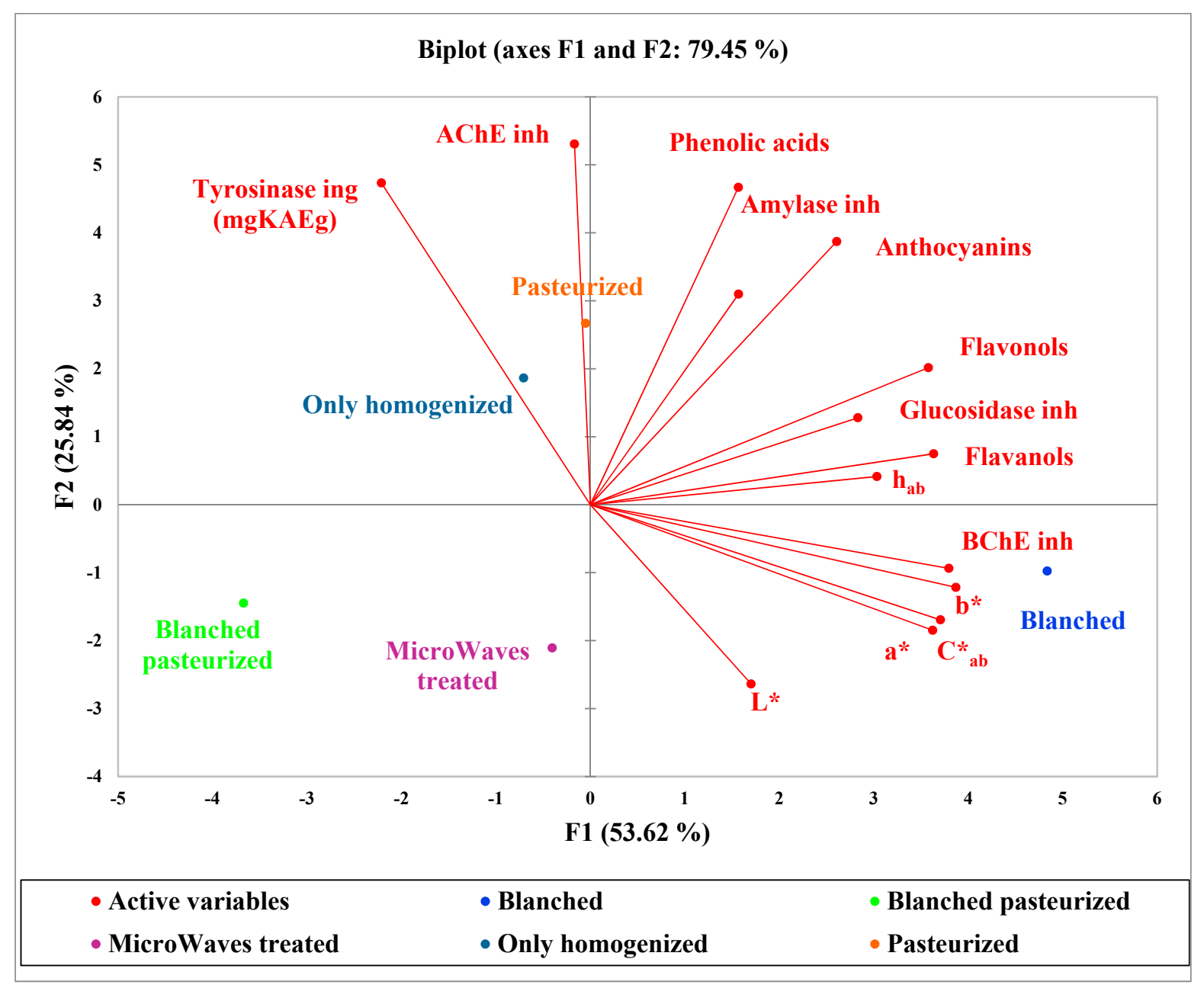

Figure 3. Principal component analysis (PCA) plots of the fresh analyzed Clery graft samples evaluated as series.

In this case, the pasteurized and only homogenized samples showed the best enzymatic inhibition activity towards tyrosinase and $\mathrm{AChE}$, and blanched were more correlated with $\mathrm{BChE}$. This difference in respect to the previously discussed results of Clery samples could be in relation to an evidently different phytocomplex composition (HPLC-DAD analysis results are reported in the Supplementary Materials). The high anthocyanins content found in the Clery samples (134-236 $\mu \mathrm{g} / \mathrm{g}$ fresh weight) [2] is significantly reduced in the Clery graft ranging between 37 to $190 \mu \mathrm{g} / \mathrm{g}$ fresh weight. This low anthocyanin 
content is also associated with a reduced content of phenolic acids (for example, caffeic acid is completely lacking), flavanols and flavonols.

In this second sample series, the interesting molecules seemed more preserved by pasteurization followed by only homogenization (second quadrant in the PCA plot, Figure 3) rather than the microwave treatment. These overall data highlighted how different very similar botanical species could be and, consequently, how much the correlated health effects could be modified in terms of specificity and magnitude. Results confirmed that the bioactivity is highly correlated to the phenolic acids and flavanols content, as previously reported in the literature [32].

In conclusion, as shown by Figure 4, in which the two series were compared, the cultivar Clery showed higher bioactivity for microwaved samples (phenolic acid content correlated with tyrosinase inhibition) and pasteurized samples (flavanol content correlated with anti-Candida activity) In the Clery graft, in which all bioactive molecules are less represented, only homogenization represented the best treatment (phenolic acid content correlated with amylase and tyrosinase inhibition).

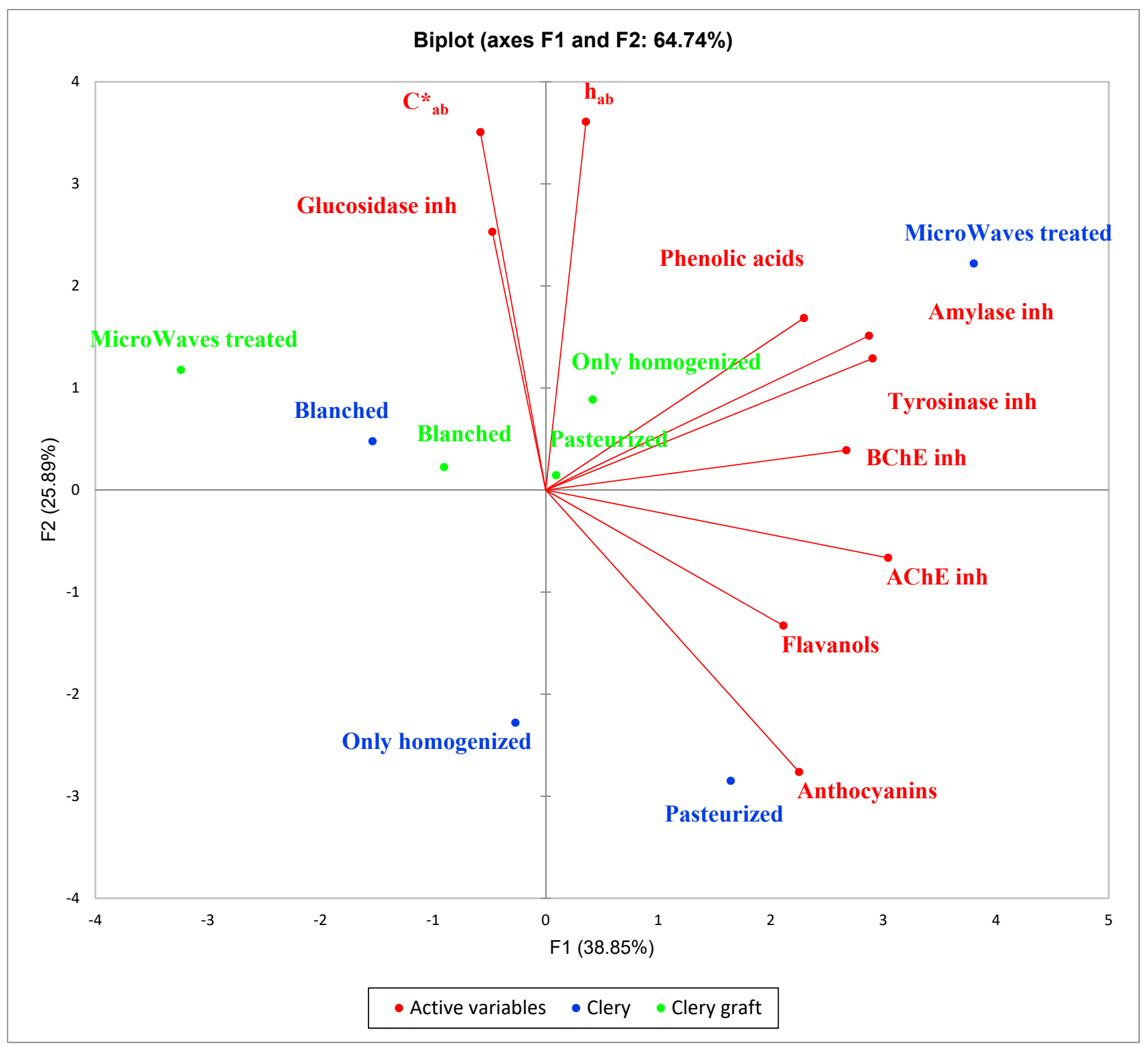

Figure 4. Principal component analysis (PCA) plots of the all strawberry samples analyzed. 


\section{Materials and Methods}

\subsection{Materials}

Clery and Clery graft on Fragaria vesca strawberries were purchased fully ripe by the farm "Fragole di Carchitti" (Palestrina, RM, $41^{\circ} 50^{\prime} \mathrm{N} 12^{\circ} 54^{\prime} \mathrm{E}$ ). A part was immediately analyzed as fresh fruit and another part was frozen at $-80{ }^{\circ} \mathrm{C}$ and stored at $-18{ }^{\circ} \mathrm{C}$ until strawberries were defrosted and the processing was performed (def and def graft). A small quantity of immature (imm) Clery was also supplied. Bidistilled water, ethanol, 85\% formic acid and acetonitrile RS for HPLC were purchased from Sigma (Milan, Italy).

\subsection{Processing}

The fully ripe fresh or thawed whole fruits were gently cleaned, if necessary, by impurities and stems and carefully washed and dried on paper. Then, they were evaluated by CIEL*a*b* color analysis according to and submitted to the different work-up and extraction procedures needed by the HPLC analysis, as previously described [2]. Color and HPLC data of Clery graft on Fragaria vesca strawberry homogenates and extracts are reported in Supplementary Materials (Tables S1 and S2).

\subsection{Determination of Enzyme Inhibitory Effects}

Inhibitory effects of the so obtained homogenized and thermally treated samples, and extracted with hydroalcoholic mixture as previously described [2] were tested against different enzymes: tyrosinase (from mushroom, EC 1.14.18.1), amylase (from porcine pancreas, EC 3.2.1.1), glucosidase (from Saccharomyces cerevisiae, EC 3.2.1.20) and cholinesterases (AChE: from electric eel, Type-VI-S, EC 3.1.1.7; BChE: from horse serum, EC 3.1.1.8). Standard inhibitors were used as positive controls (galantamine for cholinesterases; kojic acid for tyrosinase; acarbose for amylase and glucosidase). To provide comparison with standard inhibitors, $\mathrm{IC}_{50}$ values $(\mathrm{mg} / \mathrm{mL})$ were also given $\left(\mathrm{IC}_{50}\right.$ is extract concentration required for scavenging $50 \%$ of enzyme inhibitory assays). Experimental details are given in our previous paper [33].

\subsection{Antifungal Susceptibility Testing \\ 3.4.1. Antifungal Susceptibility of C. albicans}

Antifungal susceptibility of $C$. albicans was determined according to standardized methods for yeast using the broth microdilution method (CLSI M27-A3, 2008; CLSI, 2012). The strains C. albicans ATCC 10231, ATCC24433, ATCC90028, 3153A coming from the American Type Culture Collection (ATCC, Rockville, MD, USA) were grown on Sabouraud dextrose agar (Sigma Aldrich, St. Louis, MI, USA) at $35^{\circ} \mathrm{C}$ for $24 \mathrm{~h}$. The final concentration of the inoculum was $1.0 \times 10^{3}-1.5 \times 10^{3} \mathrm{CFU} / \mathrm{mL}$. The fruit extracts were dissolved previously in dimethyl sulfoxide at concentrations 100 times higher than the highest tested concentration. The extracts were then serially diluted 2-fold across the 96-well plates. The final concentrations ranged from 1.95 to $1000 \mu \mathrm{g} / \mathrm{mL}$, for all the tested samples, in RPMI 1640 medium (Sigma-Aldrich, St. Louis, MI, USA). Three experiments were performed on duplicate, on separate dates, three times for each tested extract. The panels were incubated at $35{ }^{\circ} \mathrm{C}$. After $24 \mathrm{~h}$, the minimal inhibitory concentration (MIC) was determined and the results are expressed as median. $\mathrm{MIC}_{50}$ was the lowest concentration that caused a prominent decrease $(\geq 50 \%)$ in visible growth. The $\mathrm{MIC}_{90}$ was defined as the lowest drug concentration that caused $\geq 90 \%$ growth inhibition compared with the drug-free control.

\subsubsection{In Vitro Activity of Compounds against C. albicans Biofilms}

The anti-biofilm activity was evaluated as previously described [34]. Briefly, 4\% aqueous crystal violet was added for $45 \mathrm{~min}$ and $100 \mu \mathrm{L}$ aliquots were taken from each well for absorbance measurement $(595 \mathrm{~nm})$. At least two experiments were performed on two separate experiments for each compound tested five times. 


\subsubsection{G. mellonella Survival Assay}

G. mellonella killing assays were carried out as described previously [35]. Briefly, 60 larvae of $0.3 \pm 0.03 \mathrm{~g}$ (10 for each group) were selected. Two groups were inoculated with $10 \mu \mathrm{L}$ of PU $(1000 \mu \mathrm{g} / \mathrm{mL})$ with or without $2 \times 10^{6}$ cells of $C$. albicans ATCC 10231 . A group of larvae were only pierced, a group treated with sterile PBS and a group treated with C. albicans. The larvae were then incubated at $35^{\circ} \mathrm{C}$ and monitored for $72 \mathrm{~h}$ and considered died when they did not respond to physical stimulation (a slight pressure with forceps). Each experiment was repeated at least three times and reported as percent survival rate.

\subsection{Statistical Analysis}

All analysis was performed in triplicate and the results are depicted as mean $\pm \mathrm{SD}$. To detect differences among samples, one-way ANOVA (with Tukey's test) was performed with Xlstat (Isle of Anglesey, Pentraeth, UK) 2017 software $(p<0.05$ was considered statistically significant) for determining differences in the tested samples.

\section{Conclusions}

Differently treated strawberry samples obtained by $c v$. Clery and a graft of this on F. vesca, evaluated for the best expressed activity on enzymatic inhibition of amylase, tyrosinase and acetylcholinesterase and for anti-Candida activity, confirmed the already reported potential of this edible fruit. Seasonal limited availability and consequent applied treatments aiming to preserve highly perishable foods, as previously shown, and herein confirmed, could deeply affect the phytochemical composition with high impact on the correlated bioactivity. Moreover, a great difference in terms of polyphenolic content was highlighted between the two analyzed series, despite the botanical parental filial relationship.

Clery strawberries and Clery graft were shown to be able to modulate the enzymatic activity of all the tested enzymes, with best results obtained on tyrosinase inhibition and a slight preference for $\mathrm{BChE}$ in respect to $\mathrm{AChE}$. Overall, Clery graft samples are less active, in agreement with the lower content of bioactive molecules.

The Clery series, tested along with some selected thawed and immature samples, on C. albicans activity, showed a good in vitro inhibiting potential confirmed by biofilm growth inhibition and by the in vivo test on infected G. mellonella, whose survival reached $60 \%$ at $48 \mathrm{~h}$ in respect to $0 \%$ of the reference, to which the strawberry extract was not administered.

The PCA analysis also confirmed a higher activity for the Clery samples, highlighting that, if microwaves and pasteurization represent the best treatments for this series, the only homogenization process is correlated with the best expressed activity by the Clery graft series. This result, although the graft series appears less rich in phenolics and flavonoid compounds, could account for a minor impact on bioactive substances by the fruit degradation enzymatic processes, highlighting the possibility to apply a simpler, faster and more economic flowchart, which is a goal that deserves, in our opinion, further attention.

Supplementary Materials: The following are available online, Table S1. Colorimetric CIEL*a*b* parameters of Clery graft on Fragaria vesca strawberry homogenates; Table S2. HPLC-DAD quantitative analysis of Clery graft samples.

Author Contributions: Conceptualization, S.C., G.S.; data curation G.S., G.Z.; funding acquisition S.C., M.A.C.; investigation, A.O., F.C., G.Z.; methodology, F.C., A.O., G.Z.; project administration, S.C.; resources: G.S., M.A.C.; Software: F.C.; supervision: M.A.C.; writing-original draft S.C., G.S.; writing-review and editing M.A.C. All authors have read and agreed to the published version of the manuscript.

Funding: This work was financially supported by funding from the "Sapienza" University of Rome, Ateneo 2019, RP11916B73FBB39F and Ateneo 2020, RM120172A34CFCC9.

Institutional Review Board Statement: Not applicable.

Informed Consent Statement: Informed consent was obtained from all subjects involved in the study.

Data Availability Statement: Not applicable. 
Conflicts of Interest: The author has no relevant affiliations or financial involvement with any organization or entity with a financial interest in or financial conflict with the subject matter or materials discussed in the manuscript. This includes employment, consultancies, honoraria, stock ownership or options, expert testimony, grants or patents received or pending, or royalties.

Sample Availability: Samples of the compounds are not available from the authors.

\section{References}

1. Kovačević, D.B.; Brdar, D.; Fabečić, P.; Barba, F.J.; Lorenzo, J.M.; Putnik, P. Strategies to achieve a healthy and balanced diet: Fruits and vegetables as a natural source of bioactive compounds. In Agri-Food Industry Strategies for Healthy Diets and Sustainability; Elsevier BV: Amsterdam, The Netherlands, 2020; pp. 51-88.

2. Garzoli, S.; Cairone, F.; Carradori, S.; Mocan, A.; Menghini, L.; Paolicelli, P.; Ak, G.; Zengin, G.; Cesa, S. Effects of Processing on Polyphenolic and Volatile Composition and Fruit Quality of Clery Strawberries. Antioxidants 2020, 9, 632. [CrossRef]

3. Miller, K.; Feucht, W.; Schmid, M. Bioactive Compounds of Strawberry and Blueberry and Their Potential Health Effects Based on Human Intervention Studies: A Brief Overview. Nutrients 2019, 11, 1510. [CrossRef]

4. Chen, T.; Shi, N.; Afzali, A. Chemopreventive Effects of Strawberry and Black Raspberry on Colorectal Cancer in Inflammatory Bowel Disease. Nutrients 2019, 11, 1261. [CrossRef]

5. Koch, W. Dietary Polyphenols-Important Non-Nutrients in the Prevention of Chronic Noncommunicable Diseases. A Systematic Review. Nutrients 2019, 11, 1039. [CrossRef]

6. Belizário, J.E.; Faintuch, J.; Garay-Malpartida, M. Gut Microbiome Dysbiosis and Immunometabolism: New Frontiers for Treatment of Metabolic Diseases. Mediat. Inflamm. 2018, 2018, 1-12. [CrossRef] [PubMed]

7. Fierascu, R.C.; Temocico, G.; Fierascu, I.; Ortan, A.; Babeanu, N.E. Fragaria Genus: Chemical Composition and Biological Activities. Molecules 2020, 25, 498. [CrossRef]

8. Nohynek, L.J.; Alakomi, H.-L.; Kähkönen, M.P.; Heinonen, M.; Helander, I.M.; Oksman-Caldentey, K.-M.; Puupponen-Pimiä, R.H. Berry Phenolics: Antimicrobial Properties and Mechanisms of Action Against Severe Human Pathogens. Nutr. Cancer 2006, 54, 18-32. [CrossRef] [PubMed]

9. Saxena, M. Target Enzyme in Alzheimer's Disease: Acetylcholinesterase Inhibitors. Curr. Top. Med. Chem. 2019, 19, 264-275. [CrossRef]

10. Okello, E.J.; Mather, J. Comparative Kinetics of Acetyl- and Butyryl-Cholinesterase Inhibition by Green Tea Catechins I Relevance to the Symptomatic Treatment of Alzheimer's Disease. Nutrients 2020, 12, 1090. [CrossRef] [PubMed]

11. Taslimi, P. Evaluation of in vitro inhibitory effects of some natural compounds on tyrosinase activity and molecular docking study: Antimelanogenesis potential. J. Biochem. Mol. Toxicol. 2020, 34, e22566. [CrossRef] [PubMed]

12. Carballo-Carbajal, I.; Laguna, A.; Romero-Giménez, J.; Cuadros, T.; Bové, J.; Martinez-Vicente, M.; Parent, A.; GonzalezSepulveda, M.; Peñuelas, N.; Torra, A.; et al. Brain tyrosinase overexpression implicates age-dependent neuromelanin production in Parkinson's disease pathogenesis. Nat. Commun. 2019, 10, 1-19. [CrossRef] [PubMed]

13. Cardullo, N.; Muccilli, V.; Pulvirenti, L.; Cornu, A.; Pouységu, L.; Deffieux, D.; Quideau, S.; Tringali, C. C-glucosidic ellagitannins and galloylated glucoses as potential functional food ingredients with anti-diabetic properties: A study of $\alpha$-glucosidase and $\alpha$-amylase inhibition. Food Chem. 2020, 313, 126099. [CrossRef] [PubMed]

14. Kato-Schwartz, C.G.; Corrêa, R.C.G.; Lima, D.D.S.; de Sá-Nakanishi, A.B.; Gonçalves, G.D.A.; Seixas, F.A.V.; Haminiuk, C.W.; Barros, L.; Ferreira, I.C.; Bracht, A.; et al. Potential anti-diabetic properties of Merlot grape pomace extract: An in vitro, in silico and in vivo study of $\alpha$-amylase and $\alpha$-glucosidase inhibition. Food Res. Int. 2020, 137, 109462. [CrossRef] [PubMed]

15. Spínola, V.; Llorent-Martínez, E.J.; Castilho, P.C. Inhibition of $\alpha$-amylase, $\alpha$-glucosidase and pancreatic lipase by phenolic compounds of Rumex maderensis (Madeira sorrel). Influence of simulated gastrointestinal digestion on hyperglycaemia-related damage linked with aldose reductase activity and protein glycation. LWT 2020, 118, 108727. [CrossRef]

16. Di Sotto, A.; Locatelli, M.; Macone, A.; Toniolo, C.; Cesa, S.; Carradori, S.; Eufemi, M.; Mazzanti, G.; Di Giacomo, S. Hypoglycemic, Antiglycation, and Cytoprotective Properties of a Phenol-Rich Extract from Waste Peel of Punica granatum L. var. Dente di Cavallo DC2. Molecules 2019, 24, 3103. [CrossRef]

17. Li, Q.; Wang, C.; Tang, C.; He, Q.; Li, N.; Li, J. Dysbiosis of gut fungal microbiota is associated with mucosal inflammation in Crohn's disease. J. Clin. Gastroenterol. 2014, 48, 513. [CrossRef]

18. Zhang, D.; Wang, Y.; Shen, S.; Hou, Y.; Chen, Y.; Wang, T. The mycobiota of the human body: A spark can start a prairie fire. Gut Microbes 2020, 11, 655-679. [CrossRef]

19. Pisa, D.; Alonso, R.; Juarranz, A.; Rábano, A.; Carrasco, L. Direct visualization of fungal infection in brains from patients with Alzheimer's disease. J. Alzheimer's Dis. 2015, 43, 613-624. [CrossRef]

20. Alonso, R.; Pisa, D.; Rábano, A.; Rodal, I.; Carrasco, L. Cerebrospinal Fluid from Alzheimer's Disease Patients Contains Fungal Proteins and DNA. J. Alzheimer's Dis. 2015, 47, 873-876. [CrossRef]

21. Pisa, D.; Alonso, R.; Rábano, A.; Rodal, I.; Carrasco, L. Different Brain Regions are Infected with Fungi in Alzheimer's Disease. Sci. Rep. 2015, 5, 15015. [CrossRef]

22. Wu, Y.; Du, S.; Johnson, J.L.; Tung, H.-Y.; Landers, C.T.; Liu, Y.; Seman, B.G.; Wheeler, R.T.; Costa-Mattioli, M.; Kheradmand, F.; et al. Microglia and amyloid precursor protein coordinate control of transient Candida cerebritis with memory deficits. Nat. Commun. 2019, 10, 1-15. [CrossRef] [PubMed] 
23. Fulop, T.; Witkowski, J.M.; Bourgade, K.; Khalil, A.; Zerif, E.; Larbi, A.; Hirokawa, K.; Pawelec, G.; Bocti, C.; Lacombe, G.; et al. Can an Infection Hypothesis Explain the Beta Amyloid Hypothesis of Alzheimer's Disease? Front. Aging Neurosci. 2018, 10, 224. [CrossRef]

24. Patras, A.; Brunton, N.P.; Da Pieve, S.; Butler, F. Impact of high pressure processing on total antioxidant activity, phenolic, ascorbic acid, anthocyanin content and colour of strawberry and blackberry purées. Innov. Food Sci. Emerg. Technol. 2009, 10, 308-313. [CrossRef]

25. Karacam, C.H.; Sahin, S.; Oztop, M.H. Effect of high pressure homogenization (microfluidization) on the quality of Ottoman Strawberry (F. Ananassa) juice. LWT 2015, 64, 932-937. [CrossRef]

26. Cesa, S.; Carradori, S.; Bellagamba, G.; Locatelli, M.; Casadei, M.A.; Masci, A.; Paolicelli, P. Evaluation of processing effects on anthocyanin content and colour modifications of blueberry (Vaccinium spp.) extracts: Comparison between HPLC-DAD and CIELAB analyses. Food Chem. 2017, 232, 114-123. [CrossRef] [PubMed]

27. Patsilinakos, A.; Ragno, R.; Carradori, S.; Petralito, S.; Cesa, S. Carotenoid content of Goji berries: CIELAB, HPLC-DAD analyses and quantitative correlation. Food Chem. 2018, 268, 49-56. [CrossRef] [PubMed]

28. Jacobsen, I.D. Galleria mellonellaas a model host to study virulence of Candida. Virulence 2014, 5, 237-239. [CrossRef]

29. Arvanitis, M.; Glavis-Bloom, J.; Mylonakis, E. Invertebrate models of fungal infection. Biochim. Biophys. Acta (BBA)-Mol. Basis Dis. 2013, 1832, 1378-1383. [CrossRef]

30. Al Aboody, M.S.; Mickymaray, S. Anti-Fungal Efficacy and Mechanisms of Flavonoids. Antibiotics 2020, 9, 45. [CrossRef]

31. Grussu, D.; Stewart, D.; McDougall, G.J. Berry Polyphenols Inhibit $\alpha$-Amylase in Vitro: Identifying Active Components in Rowanberry and Raspberry. J. Agric. Food Chem. 2011, 59, 2324-2331. [CrossRef]

32. Xiao, J.; Ni, X.; Kai, G.; Chen, X. A Review on Structure-Activity Relationship of Dietary Polyphenols Inhibiting $\alpha$-Amylase. Crit. Rev. Food Sci. Nutr. 2013, 53, 497-506. [CrossRef] [PubMed]

33. Uysal, S.; Zengin, G.; Locatelli, M.; Bahadori, M.B.; Mocan, A.; Bellagamba, G.; De Luca, E.; Mollica, A.; Aktumsek, A. Cytotoxic and Enzyme Inhibitory Potential of Two Potentilla species (P. speciosa L. and P. reptans Willd.) and Their Chemical Composition. Front. Pharmacol. 2017, 8, 290. [CrossRef] [PubMed]

34. Taff, H.T.; Nett, J.E.; Andes, D.R. Comparative analysis of Candidabiofilm quantitation assays. Sabouraudia 2012, 50, 214-218. [CrossRef]

35. Li, D.-D.; Deng, L.; Hu, G.-H.; Zhao, L.-X.; Hu, D.-D.; Jiang, Y.-Y.; Wang, Y. Using Galleria mellonella-Candida albicans Infection Model to Evaluate Antifungal Agents. Biol. Pharm. Bull. 2013, 36, 1482-1487. [CrossRef] [PubMed] 